\title{
sciendo
}

\section{In order to thrive, first we need to fix accounting and management Then, we must report what matters}

\author{
Marius PANTAZI \\ Bucharest University of Economic Studies, Bucharest, Romania \\ marius.pantazil@gmail.com
}

\begin{abstract}
This paper examines the role of accounting through the information it provides to stakeholders, as well as the role of accounting in the development of our society. Accounting is vital for society, it is the main tool used to run businesses and state institutions, companies are decisive for defining culture, and culture is the basis of a developed society. Societies rely on its institutions, and the solution for a better world is found in the usage of reliable and independent data. It is well known the fact that subjective management decisions based on creative accounting led to big crises with negative consequences for all. Accounting has been used as the main tool to assess performance, but in order to be even more useful for society, the accounting system needs to modernize and unite, be transparent and totally independent from management. And it should be even more connected to the business model and responsive to the needs of society, in order to be able to provide valuable, comparable and useful information for all parties involved. The paper advocates for independent and forward-looking accounting, by giving up the flexibility, creativity and influence of managers, for decisions based on detailed and concrete information, transferred and consolidated in real time with the help of technology. Now accounting has the capacity to control the business and bring value to society through real-time and high-quality business reporting.
\end{abstract}

Keywords: automation, business, management, real-time accounting, high quality reporting, business and social performance.

\section{Introduction}

"Accounting has played a vital role in the development of modern society" (Hopwood, 1976). Due to benefits of technological progress, accounting could be even more helpful, correcting poor processes and improving economic as well as ethical performance.

Accounting is deeply involved in the lives of individuals, organizations and society, while being the cause and effect of complex social and economic processes (Burchell et al., 1985). Weber believes that society and accounting need to be studied together to better understand their close relations (Weber, 1947).

Kate Raworth believes that economic theory will play a decisive role in addressing the great challenges of the moment, challenges related to inequity, poverty, the environment, and economic science is the mother tongue of politics and the one that can shape society (Raworth, 2017).

Accounting represents the public interest and the accountant is the guarantor of ethical practices in an organization. Therefore, the "true image" must be the ideal of accountants, an image that represents the most accurate economic and social reality. "Exact representation: the information must present exactly the phenomena it aims to reflect. To be an accurate, perfect representation, the description must have three characteristics: it should be complete, neutral and error-free" (Ristea \& Dumitru, 2012). There is only one picture of reality, and accounting normalizers must continue to improve the accounting system, modernizing it and giving up alternative treatments that are still at the discretion of managers. Michel Capron argues that the idea that there are several true images of the same reality has been accredited, but since accounting can only provide one representation of reality, the question arises is not to confuse the image with reality (Capron, 1994). 
Organizations need to focus on the long term, but at the same time, leaders must deliver strong performance today and have the capacity and vitality to reinvent the business and grow sustainably through continuous innovation and reinvention. However, the very long-term plans are not a recommendation from Keynes ${ }^{1}$.

Regardless of industry, organizations are responsible for how a society is run, so we should be much more involved in how businesses are governed if we want to make our world a better place.

In addition to many benefits to society, such as generating revenue for states through taxes, developing innovative ideas and creating exciting new products, stability and security for citizens, there is one extraordinary thing that organizations can achieve, one that Milton Friedman did not understand when he declared that the social responsibility of organizations is to increase shareholder profits (Friedman, 1970). Organizations can be an example for society as a whole to improve the world. They can draw attention to important issues of humanity and inspire the next generation, starting to solve issues related to race relations, inequality, the environment, education and other areas of interest to humanity (Pantazi, 2020).

\section{Literature review}

Guess who has been at the root of the biggest corporation's bankruptcies and the big 2008 crisis! Yes, it was easy to guess, due to overwhelming evidence. Two factors are to be blamed: management and poor, flexible, creative and easy to manipulate accounting. But IASB's chairman (Hoogervorst, 2018) says that for the accounting standards to do their job properly, we need management to own up to the facts and auditors, regulators and investors to be vigilant. We believe that only an accounting system that is totally independent from the management would solve these issues. And due to near universal adoption of automation in the next five years (Wright et al., 2017), accounting could be modernised so that it would provide reliable, independent and real time information.

Rebecca Lester and S.P. Kothari explain in their paper that, in addition to many other reasons, two factors contributed in part to the 2008 economic crisis: management incentives and accounting standards that enable the valuation of certain assets at fair value (Kothari \& Lester, 2012). And Nobel Prize winner, Joseph Stiglitz, points out that mark-to-market incentives and accounting played an important role in financial market scandals in the late 1990s (Enron/Worldcom) and the 2007/2008 financial crisis. Executive management compensation schemes, combined with bank accounting regulations, have encouraged the provision of misleading information, the recording of "above the line" revenues and the highlighting of off-balance sheet liabilities. Directors who are paid stock options have an incentive to increase the market value of shares, and this can be done more easily by increasing reported revenues than by increasing real profits (J E Stiglitz, 2009). Defond and his colleagues came to the conclusion that fair value accounting may reduce the usefulness of earnings in executive performance evaluation by reducing the reliability of reported earnings (DeFond et al., 2020). Another study from Jordan extracted data from 45 companies' annual reports during a ten-year period (1997-2006) five years before and after the application of fair value to examine the relationship among the application of fair value accounting and the presence of manipulation in financial statements. The result indicates that the number of firms that manipulated information in the financial statements had increased after applying fair value accounting (Alaryan et al., 2014). “Enron's accountants (with Andersen's

\footnotetext{
${ }^{1}$ John Maynard Keynes famous quote: "In the long run we are all dead".
} 
approval) used accounting devices to report cash flow from operations rather than financing and to otherwise cover up fair-value overstatements and losses on projects undertaken by managers whose compensation was based on fair values. Based on a chronologically ordered analysis of its activities and investments, I believe that Enron's use of fair-value accounting is substantially responsible for its demise" (Benston, 2006).

Robert Sterling concluded that we accountants do not resolve issues in accounting, we abandon them, moving from one unresolved issue to another, and the explanation for this inability to solve issues is to be found in the way we conceive of the issues. Let's just consider the FIFOLIFO (still used on US GAAP) long debate (Sterling, 1975). In an era where physicists have discovered quantum internet, do we still need to choose between FIFO, WAC and LIFO (US GAAP only) to calculate the cost of inventories in today's advanced systems for items that are interchangeable? From our analysis, on 88 companies, all of them used specific identification of cost for all inventories. According to IAS 2, specific identification of cost means that specific costs are attributed to identified items of inventory. We argue that only in very few cases, when specific identification of cost cannot be used, organizations should use only FIFO method, because it is logical and natural and "materials in stock must be in the order of their entry so that no losses occur due to damage or moral wear" (Ristea \& Dumitru, 2012).

Below are the opinions expressed in the book Freedom and Compliance in Accounting Standards and Regulations by G. Petre and Collective, 2010; They believe that accounting policies could be designed so that a company can "maximise profit" by changing accounting rules. Ristea and Dumitru describe that professors Alain Burlaud and Bernard Colasse do not agree with the $4^{\text {th }}$ European Directive, which explains that there is one image of a company, an independent reality which is the same for all involved parties. They consider that there are as many images of the enterprise as observers are involved, and that accounting representation means a construction and not a mere return of an object. Our opinion is that there is only one image of an enterprise and, with the help of technology, we can measure

From our point of view, this thinking is wrong and consequently, we do not agree with it: "The strategy of the company concerned must be considered when setting accounting policies, i.e., whether the company is seeking immediate high profits or is pursuing development through new investments in technology. In the first case, when the company wishes to maximise profit, accounting policies will include rules leading to the lowest possible expense in the profit and loss account." "Among the possibilities for recording reduced expenditure in the accounts, we show the next examples: Using the first-in-first-out (FIFO) method to calculate the cost of stocks consumed; Establishing long economic lifetimes for tangible assets and therefore amortising them for as long as possible, returning an expense with reduced depreciation in the profit and loss account; Capitalisation of interest, i.e. the introduction into the value of long-cycle assets of interest due for the period, for loans contracted by the company to finance the acquisition or construction of longterm assets..." (Ristea \& Dumitru, 2012).

The information must be reliable according to the IASB General Framework, i.e., it does not contain significant errors and is not biased; if "the company wants to maximise profit" and chooses the FIFO method, then the information is biased. We should get rid of such approach and let accounting report the exact reality, without any intervention from the management. The only way to maximise profits of an organization is to optimise processes so that the organizations become more efficient.

Related to consumptions, it is desirable to know exactly the evolution of consumption; for example, real-time consumptions based on the specific identification method can help managers 
rearrange goods on supermarket shelves, seeing that fresher goods are sold before older ones due to their misarrangement in shelves. What value could management bring, which wants to "maximize profit", or on the contrary, minimize it in order to "develop through new investments", in a decision on depreciation of some machinery, when it has already been established by the accounting professionals together with the engineer who is responsible for the project? They took the decision to depreciate those machines on the basis of detailed business plans, analysing operating hours and period of use, linking depreciation with the procurement budget and new contracts with suppliers. The external audit then validated the chosen method by checking the documents as well as the accounting standards and rules.

What opinion could management have in the inventory discharge method when they are automatically calculated by specific identification? Why let management decide on matters strictly related to accounting judgment, beyond the will of accounting professionals who are in no way linked to the results obtained by companies? Even in the field of research, which has the highest ethical standards, it has been shown that researchers, under stress, can be biased (Fanelli, 2010).

\section{Methodology}

The paper analyses the practices of some Romanian companies, Romanian legislation and international standards in the field of accounting, as well as scientific articles, studies and specialized books, aiming to express particularly bold opinions that, we hope, will have beneficial effects on the accounting profession and on society. Related to practices from Romanian companies, we have analysed 88 companies. We have divided them into two groups, the first group (group A) being composed of 84 small companies with a maximum of 50 employees, and the second group (group B) consists of four multinational companies, which have between 200 and 1,000 employees. Comparisons between practices of companies and accounting rules requirements will be made, in order to emphasise important differences.

The paper tries to fill the gap between academic research and practice. "Research in accounting and management in general has been criticized for straying too far from the practices and activities it seeks to investigate and improve" (Hopwood, 2007).

It is a constructivist work of a qualitative type, which offers an analytical depth of the cases studied.

\section{Results and discussions}

\section{Accounting is not an art}

Accounting was considered an art by Luca Pacioli himself in a 1514 work. At the time, the accounting "was regarded as superior to all others" (Ionascu, 1997), quoting Demetrescu ${ }^{2}$, and was even "kept secret or the accountants did not bother to show it to others". Even recently, the chairman of the International Accounting Standard Boards, Hans Hoogervorst, has declared that accounting is highly dependent on the exercise of judgment and is therefore more an art than a science (Hoogervorst, 2018). But "the purpose of an artist is to present his personal interpretation of an object, not to present an accurate representation of that object"'(Sterling, 1975), and defining accounting as an art, we leave ourselves open to receiving instructions and threads. Sterling continues and says that the artist is instructed to "paint the portrait": "Flatter me just a little-a 10 per cent increase in earnings per share would be about right. Conceal my warts and pimples with cosmetically phrased footnotes".

${ }^{2}$ C.G. Demetrescu, Istoria Contabilităţii, Editura Științifică, București, 1972, p.62. 
The core purpose of rigorous accounting, Charles Lee contends, is to provide economic history, an accurate report on transactions that have already occurred (Lee, 2014). There is no need anymore to be artists, we just need to provide a "true and fair view" of the statements.

\section{Cost Accounting - We need to change the old thinking}

When it comes to recognition and registration of expenses, we need to change our thinking and focus on calculating actual costs, i.e., in the short term, not standard costs, which are calculated considering longer time periods. Now the technology gives us the opportunity to record costs in real time. In the book - Cost Accounting, A Managerial Emphasis (Horngren et al., 2015), a reference book in managerial accounting, the emphasis is on calculation over a period of one year. "There are two reasons for using longer periods of time, such as a year, to calculate indirect costs". They continue: "For example, if indirect-cost rates were calculated each month, the costs of heating would be charged to production only during the winter months. An annual period incorporates the effects of all four seasons into a single, annual indirect-cost rate". But today we can no longer afford such an approach. We should use the actual costs of production, for the simple reason that we want to know the actual cost of a product. Managers should know that their products made in the winter months are more expensive, and because of this, profit margins will be lower. Higher production costs will also generate higher payments to suppliers, and thus greater needs for financial resources. The fact that sales prices are the same throughout the year is due to a sales strategy and should not influence the calculation of costs. Accounting should provide exactly the economic reality in order for decisions to be taken in full knowledge of the facts. The production cost budget is connected to the cash flow budget, and any erroneous information will have adverse effects.

Other opinions of the above-mentioned authors are described as follows: "Levels of total indirect costs are also affected by nonseasonal erratic costs. Nonseasonal erratic costs are the costs incurred in a particular month that benefit operations during future months, such as equipment-repair costs and the costs of vacation and holiday pay for employees. If monthly indirect-cost rates were calculated, the jobs done in a month in which there were high, nonseasonal erratic costs would be charged with these higher costs". We strongly affirm that these nonseasonal erratic costs should not be treated directly as expenses, as long as they offer future economic benefits to the company, even for a few months. Why do we still stick to the one-year period? One month over one year means current assets and one month more than a year means long term assets? Of course not, it's just a limitation of the old thinking that should be changed. For example, if a machine, in order to operate at normal parameters, needs to be repaired three times a year, then the repair should be considered an asset, "Regular repairs"- let's say, and staggered over the four-month period. It should be noted that such an approach is not found in national law, OMFP 1802/2014, European Directives or the IFRS framework. Only revisions and inspections whose costs are significant, such as aircraft, ships or other complex equipment, are considered. But why only these? We emphasize once again the fact that accounting should report the most accurate economic and social reality. No matter what.

The costs of vacation and holiday pay for employees must not be recorded as an expense in the accounts at the time of their payments, as described in the book and also in Romanian legislation. This means that if a person has one month of vacation, then the company shouldn't have any expense in accounting with that person. Vacation on the payroll should never be treated as an expense, they mean just a payment of an obligation, if it was earned according to the contract, and an advance, that means an asset, if the vacation wasn't earned before. For example, if an 
employee is entitled to 22 days of vacation per year, it follows that after one month of work he is entitled to 2 days of vacation. This cost shall be recorded in the month it was earned, and then month by month automatically registered to the projects on which the employee worked. The vacation payment only lowers the obligation of the company thus constituted. Note that this treatment is consistent with IAS 19- Employee Benefits. In our study, companies in Group A (small companies) do not record at all the costs of holidays not performed, while companies in Group B record these costs at the end of the year, as a provision. The expected future economic benefits of companies, whether less than one year or more, must be staggered over the estimated period so that the cost of production and services can be calculated on a real basis.

\section{Profit and loss account - indicator of a company's economic performance - Structural problems and a remedial proposal}

According to IAS 1, the Profit and Loss Account can be presented in two ways, with the grouping of expenses by nature or by economic destination. None provides the information needed for an effective analysis of the results obtained by companies. The IASB ${ }^{3}$ itself recognizes that the financial statements prepared by the economic entities satisfy only part of the information needs of these users and is aware that the content of these financial statements should be improved (IASB, 2015). This is at least strange given the level of development of science and technology.

\section{Romania case}

If we look at the Profit and Loss Account in Romania, a list format with the presentation of operating expenses by their economic nature, we observe that it has been taken over almost entirely according to the 4th European Directive. We find that we cannot extract from the form the most important indicator of financial performance: gross margin! Users of the information are unable to find out whether a company is selling a product or service at a value above the cost of production. If we also look at the information presented in the note "Analysis of operating income", to calculate the most important indicator of financial performance, we find that the indicator Cost of goods sold and services rendered- is wrong! "The indicator - The cost of goods sold and services rendered- should cover only expenditure on goods sold and not all production costs related to goods obtained during the period" (Jianu, 2007). Professor Iulia Jianu also adds that the Note's model is not in line with the requirements of IAS 1 for the presentation of operating expenses by the company's functions.

Instead, a correction account is used, account that is presented in the revenue section, called "Stock Variation", which only annoys information users and even accounting professionals. "The profit and loss account in its format as list, with the grouping of expenses by nature, presents the account "Stock Variation" at the revenue section, with the plus sign in the case of an increase of stocks, and with the minus sign in the case of a decrease, and not at the expenses section, as provided for in IAS1" (Jianu, 2007). Other authors also believe that this presentation is questionable (Malciu \& Feleagă, 2005), while Man and Gădău consider that this account should be only a correction of production expenditure, because it basically reflects production costs, as an expression of the benefits consumed and not of the benefits obtained (Man \& Gădău, 2011).

As a result, we have the strange situation in case of companies that did not realize any sales, but they report in their financials revenues. Or companies that report more revenues that they really

\footnotetext{
${ }^{3}$ International Accounting Standards Board- independent body responsible for the development and publication of the IFRS standards.

${ }^{4}$ Now it is called "Revenues associated to the production cost", but has the same functionalities.
} 
realized, as we will see in an example below. This thing is simply untrue. The same thing is also valid for the so much criticized Fair Value Accounting, which leads to recognition of revenues that are unrealized. Professor Charles Lee believes that "fair-value accounting goes against the fundamental purpose of accounting. It would actually inject more uncertainty into financial reporting and make life harder for shareholders. It might even create new opportunities for companies to cook their books" (Lee, 2014).

Our view is that this account should not appear on revenue side, regardless of its final balance, for the simple reason that it does not meet any conditions to be recognized as income. The solution is a simple one and is based on a combination of the two presentation methods, so that we have a single Profit and Loss Account form that satisfies all users. But first let us see the shortcomings of the second method, as well as a practical analysis of the two presentations.

If we look at the other way of presentation, expenses recognised by function, we will notice that the company's performance is very well expressed. However, this model does not allow for detailed analysis of expenditure, by its nature, which provides an analysis of the structure and types of expenditure incurred.

In the section - Figures and Tables -, we have a projection of the Profit and Loss AccountTable 1. Profit and Loss Account- assumed and published by the company that owns the brand "Dairy Cream", a public limited company that wants to list on the Bucharest Stock Exchange, through BT Capital Partners, in order to attract funds from the capital market through a bond issue.

The company submitted the Profit and Loss Account to the Stock Exchange in accordance with national regulations. We have noted that the "Stock Variation" account appears on revenue side, which distorts the most important indicator of economic performance, gross margin. We have the following remarks:

Gross profit is artificially increased by including the "Stock Variation" account in revenue. Our opinion is that the gross margin is misrepresented, and this is due to the structure imposed by the accounting normalisers. This structure has confused even the accounting professionals who drew up the situation.

The company's costs are also artificially increased, a natural consequence of artificial revenue growth. We have the "Cost of Goods Sold" account, which includes personnel costs, materials, services, depreciations, but we also have all company costs presented. In the standardised format required by the normalizers, we do not have the account "Cost of goods and services produced" but only "Cost of goods sold". Here the company tried to present "Gross Margin", an indicator that does not exist in the Profit and Loss Account format in this format.

If "Stock Variation" was not enough to annoy all stakeholders, then we have another issue: Fair Value Accounting. For the company we talked above, a company from agriculture field, applying Fair Value Accounting means to recognise a part of revenue during the production process, when milk and other agricultural products are obtained, and when the finished goods are sold, the total revenue, so that in the end, reported revenue is higher than the real one and gross margin is mistaken.

One of the fundamental characteristics of financial information is the relevance, according to the IASB's General Conceptual Framework (IASB, 2015). How relevant is "Stock Variation" for users? Not only that it is not relevant for users, but it is also strongly challenged by academia and very difficult to be used by professionals. Let's just think about how difficult, we think it's impossible, to estimate "Stock Variation" over three or five years. If we add the estimate of revenues related to ongoing services as well as income from the production of fixed assets, we 
conclude that any reasonable estimate based on the structure of the Profit and Loss Account required by the European Directive is impossible to be realised.

As a result, our proposal is to change the structure of the Profit and Loss Account by removing from the declared income the following accounts: changes in stocks, revenues related to the costs of services, as well as income from the production of fixed assets, and any revenue related to Fair Value Accounting.

After a brief analysis of the other model, expenses recognised by function, we will propose a model to cover the shortcomings of the two models.

Table 2. Apple Inc. -Profit and Loss Account, see the section - Figures and Tables -, is the model with the grouping of expenses by economic destination, reporting expenses by company functions. The model is from Apple's public site, so the format is in line with the American reference.

Margins for the sales of goods and services are clearly presented, allowing users to form an opinion about the company's economic performance. The company's functions are well delineated, but this model does not provide the possibility to analyse the nature of the expenses. Can we compare the two companies? Of course not. But how about comparing thousands of companies in an instant in today's advanced myriads of software?

In the section -Figures and Tables- we have the proposed Profit and Loss Account, composed of Table 3. Proposed Profit and Loss Account and Table 4. Value of Capitalized Expenses.

The model of the Profit and Loss Account proposed, together with the Value of Capitalised Expenses, the grouping of expenses by the functions of a company, but also a classification of expenses by their nature, in order to be able to calculate indicators such as the production of the year, value added, as well as the carrying out of macroeconomic analyses on the structure of Gross Domestic Product and other necessary statistics at macroeconomic level. At the same time, the form fully meets the most demanding requirements of investors.

We have no doubt that such a report can be presented without much effort by any organization, and we even argue that, thanks to technology, reporting only means the automatic consolidation of data entered into the system. The advantages are huge, such as, for example, comparability in space, essential quality of information, according to the general IASB framework, and it is now possible to make real comparisons between companies. Now, investors and other stakeholders can analyse, use data in any report and compare any company.

The need for a more detailed Profit and Loss Account that meets all the needs of stakeholders is also due to the fact that the financial statements, according to the authors of The end of Accounting (Lev \& Feng, 2016), have become less useful for investor decision-making. In an increasingly digitised world, accounting revenues and profits are virtually irrelevant, at least to digital companies, and the current system cannot detect value creation (Govindaranjan et al., 2018). The authors give the example of companies like Uber or Airbnb, which do not have tangible assets, cars or real estate on their balance sheets, but which are worth billions of dollars on the stock exchange, which report huge losses year after year, and yet their shares grow exponentially. So, the value of a digital company cannot be tracked by looking at the figures in the balance sheet. That is why, it is of a paramount importance that Profit and Loss Account to report expenditures with research and development and other important expenses such as for brands, organizational strategy, partner and supplier networks, customer relations and social relations, computer data and software and human capital. All these essential elements are found in the Profit and Loss Account rather than in the company Balance Sheet. Many of these expenses are not capitalised, that is why there 
is a big difference between book value and market value in case of successful companies. Despite this situation, intangible assets already exceeded tangible assets as the main way of capital creation for U.S. companies (Enache \& Srivastava, 2018).

\section{Figures and tables}

\begin{tabular}{|c|c|c|c|c|c|c|}
\hline \\
\hline RON & 2020E & $2021 F$ & 2022F & $2023 F$ & $2024 F$ & $2025 \mathrm{~F}$ \\
\hline Total Revenue & $69,928,873$ & $86,035,213$ & $104,868,825$ & $119,585,046$ & $130,543,020$ & $141,553,326$ \\
\hline Sales & $46,163,674$ & $59,526,000$ & $73,835,188$ & $85,247,200$ & $93,968,124$ & $102,850,192$ \\
\hline Stock Variation & $16,500,000$ & $20,680,755$ & $24,913,756$ & $27,911,970$ & $29,827,727$ & 31,618 \\
\hline Other Revenue & $7,265,199$ & $5,828,459$ & $6,119,882$ & $6,425,876$ & $6,747,169$ & $7,084,528$ \\
\hline Cost of Goods Sold & $(38,460,880)$ & $(40,866,726)$ & $(47,190,971)$ & $(50,823,644)$ & $(52,217,208)$ & $(56,62$ \\
\hline Gross Profit & $31,467,993$ & $45,168,487$ & $57,677,854$ & $68,761,401$ & $78,325,812$ & 84, \\
\hline Employee Expense & $, 568,527)$ & $11,372,878)$ & $13,306,267)$ & $(14,146,040)$ & $15,031,705)$ & $(15,96$ \\
\hline Rental E & & & & & & \\
\hline $\begin{array}{l}\text { Maintenance } \\
\text { repair expens }\end{array}$ & $(1,606,655)$ & $(1,686,988)$ & $(1,771,338)$ & $(1,948,471)$ & $(2,143,318)$ & $(2,250,484)$ \\
\hline Marketing Ex & 72,894) & 520) & T & 161969 & 17 & $(1,85$ \\
\hline t of Goods & $(3,085,948)$ & $(3,571,560)$ & $(4,245,523)$ & $(4,688,596)$ & $(4,933,326)$ & $(5,142,510)$ \\
\hline Third party expenses & V) & 0) & $(6,645,167)$ & 厂 & (6 577769$)$ & 2) \\
\hline $\begin{array}{l}\text { Other operating } \\
\text { expenses }\end{array}$ & $(2,308,184)$ & $(2,619,144)$ & $(3,174,913)$ & $(3,580,382)$ & $(3,852,693)$ & $(4,114,008)$ \\
\hline EBITD & $9,124,569$ & $18,573,581$ & & & & $9,287,089$ \\
\hline $\begin{array}{l}\text { Depreciation and } \\
\text { Amortisation } \\
\text { Expenses }\end{array}$ & $, 000)$ & $, 000)$ & $, 000)$ & $0,000)$ & $0,000)$ & $0,000)$ \\
\hline Operating Profit & 4,569 & 81 & 60 & & 90 & 87,089 \\
\hline Interest Expenses & 000) & 813) & (,813) & $(3,467,813)$ & 7,813) & $(3,367,813)$ \\
\hline $\begin{array}{l}\text { Other Financial } \\
\text { Expenses }\end{array}$ & 0 & 0 & U & 0 & 0 & 0 \\
\hline Corporate Tax & U & 0 & & & 39) & 704) \\
\hline Net Profit & $2,775,431)$ & $7,805,769$ & $15,877,048$ & $23,313,595$ & $30,999,239$ & $36,023,313$ \\
\hline
\end{tabular}

PICBE |

Table 2. Apple Inc. -Profit and Loss Account

\begin{tabular}{|l|r|r|r|}
\hline $\begin{array}{c}\text { Consolidated Statements of Operations } \\
\text { (in millions \$) }\end{array}$ & $\begin{array}{c}\text { September 28, } \\
\mathbf{2 0 1 9}\end{array}$ & $\begin{array}{c}\text { September } \\
\mathbf{2 8 , 2 0 1 8}\end{array}$ & \multicolumn{1}{c|}{$\begin{array}{c}\text { September 28, } \\
\mathbf{2 0 1 7}\end{array}$} \\
\hline Net Sales: & & & \\
\hline Products & 213,883 & 225,847 & 196,534 \\
\hline Services & 46,291 & 39,748 & 32,700 \\
\hline Total net sales & 260,174 & 265,595 & 229,234 \\
\hline Cost of Sales: & & & \\
\hline Products & 144,996 & 148,164 & 126,337 \\
\hline Services & 16,786 & 15,592 & 14,711 \\
\hline Total cost of sales & 161,782 & 163,756 & 141,048 \\
\hline Gross Margin & 98,392 & 101,839 & 88,186 \\
\hline & & & \\
\hline Operating expenses: & & & \\
\hline Research and development & 16,217 & 14,236 & 11,581 \\
\hline Selling, general and administrative & 18,245 & 16,705 & 15,261 \\
\hline Total operating expenses & 34,462 & 30,941 & 26,842 \\
\hline
\end{tabular}




\begin{tabular}{|c|c|c|c|}
\hline $\begin{array}{c}\text { Consolidated Statements of Operations } \\
\text { (in millions \$) }\end{array}$ & $\begin{array}{c}\text { September 28, } \\
2019\end{array}$ & $\begin{array}{c}\text { September } \\
28,2018\end{array}$ & $\begin{array}{c}\text { September 28, } \\
2017\end{array}$ \\
\hline Operating income & 63,930 & 70,898 & 61,344 \\
\hline Other income/(expense), net & 1,807 & 2,005 & 2,745 \\
\hline Income before provision for income taxes & 65,737 & 72,903 & 64,089 \\
\hline Provision for income taxes & 10,481 & 13,372 & 15,738 \\
\hline Net income & 55,256 & 59,531 & 48,351 \\
\hline
\end{tabular}

Table 3. Proposed Profit and Loss Account

\begin{tabular}{|c|c|c|}
\hline Indicators & Current year & Previous year \\
\hline \multicolumn{3}{|l|}{ Revenue from net sales: } \\
\hline -Goods & $1,500,000$ & $1,200,000$ \\
\hline -Services & $1,000,000$ & 800,000 \\
\hline TOTAL- NET REVENUE & $2,500,000$ & $2,000,000$ \\
\hline \multicolumn{3}{|l|}{ Cost of Sales: } \\
\hline -Goods & 950,000 & 790,000 \\
\hline -Services & 450,000 & 300,000 \\
\hline TOTAL -COST OF SALES & $1,400,000$ & $1,090,000$ \\
\hline GROSS MARGIN & $1,100,000$ & 910,000 \\
\hline \multicolumn{3}{|l|}{ Direct Sales Expenses: } \\
\hline -Salary Expenses & 140,000 & 112,000 \\
\hline -Material Expenses & 90,000 & 72,000 \\
\hline -Depreciation and Amortization Expenses & 38,000 & 30,400 \\
\hline -Third Party Expenses & 29,000 & 23,200 \\
\hline TOTAL DIRECT SALES EXPENSES & 297,000 & 237,600 \\
\hline \multicolumn{3}{|l|}{ Research and Development Expenses: } \\
\hline -Salary Expenses & 30,000 & 24,000 \\
\hline -Material Expenses & 9,500 & 7,600 \\
\hline -Depreciation and Amortization Expenses & 2,300 & 1,840 \\
\hline -Third Party Expenses & 1,900 & 1,520 \\
\hline TOTAL RESEARCH AND DEVELOPMENT EXPENSES & 43,700 & 34,960 \\
\hline \multicolumn{3}{|l|}{ General, Administrative and Selling Expenses: } \\
\hline -Salary Expenses & 200,000 & 160,000 \\
\hline -Material Expenses & 30,000 & 24,000 \\
\hline -Depreciation and Amortization Expenses & 26,000 & 20,800 \\
\hline -Third Party Expenses & 34,000 & 27,200 \\
\hline TOTAL GENERAL, ADMINISTRATIVE AND SELLING EXPENSES & 290,000 & 232,000 \\
\hline OTHER OPERATING INCOME & 500,000 & 400,000 \\
\hline \multicolumn{3}{|l|}{ Other Operating Expenses: } \\
\hline -Salary Expenses & 2,900 & 2,320 \\
\hline
\end{tabular}




\begin{tabular}{|l|r|r|}
\hline \multicolumn{1}{|c|}{ Indicators } & \multicolumn{1}{c|}{ Current year } & \multicolumn{1}{c|}{ Previous year } \\
\hline -Material Expenses & 3,000 & 2,400 \\
\hline -Depreciation and Amortization Expenses & 2,500 & 2,000 \\
\hline -Third Party Expenses & 3,000 & 2,400 \\
\hline TOTAL OTHER OPERATING EXPENSES & 11,400 & 9,120 \\
\hline Profit (Loss) before interest and tax (EBIT) & 957,900 & 796,320 \\
\hline -Revenue related to affiliated entities & 150 & 120 \\
\hline -Interest Income & 25 & 20 \\
\hline -Interest Expenses & 2,000 & 1,600 \\
\hline -Other Financial Income and Expenses, Net Result & 900 & 720 \\
\hline PROFIT (LOSS) BEFORE TAX & 955,175 & 794,140 \\
\hline -Corporate Tax & 152,828 & 127,062 \\
\hline Net Profit/(Loss) of the year & 802,347 & 667,078 \\
\hline
\end{tabular}

PICBE |

Table 4. Value of Capitalized Expenses

\begin{tabular}{|l|r|r|}
\hline Indicators & Current year & Previous year \\
\hline Capitalized Production Expenses (Value of Production Obtained): & & \\
\hline -Salary Expenses & 800,000 & 640,000 \\
\hline -Material Expenses & 70,000 & 56,000 \\
\hline -Depreciation and Amortization Expenses & 350,000 & 280,000 \\
\hline -Third Party Expenses & 250,000 & 200,000 \\
\hline -Interest Expenses & 45,000 & 36,000 \\
\hline $\begin{array}{l}\text { VALUE OF OBTAINED PRODUCTION, EXPRESSED IN EFFECTIVE } \\
\text { PRODUCTION COSTS }\end{array}$ & $1,515,000$ & $1,212,000$ \\
\hline
\end{tabular}

Source: Author's own projection.

\section{Conclusion}

Psychologists and economists believe that human beings adjust their behaviour based on the metrics they are held against (Ariely, 2020), therefore, if accounting continues to report information related to customer and employees' satisfaction, how much carbon dioxide is emitted in the atmosphere, or other information about inequality, environment, level of education and health, then we have a big chance to succeed in attaining those metrics and the world will become a better place for everybody (Pantazi, 2020).

There is no doubt that automation is the main preoccupation for most of the companies. According to Deloitte's 2017 RPA survey, market trending is indicating near-universal adoption of Robotic Process Automation (RPA) in the next five years (Wright et al., 2017). Automation will affect one third of all jobs in the next 10 years, while technology could create millions of jobs (Fleming, 2020) (Hawksworth et al., 2018). The problem is that we are not prepared for the requirements of the new jobs, and Kate Raworth warns us that there are lots of incentives for using robots, but none for humans development (Raworth, 2017), and we need to shift our thinking from unlimited GDP growth to a more sustainable goal, that could ensure dignity and prosperity for all people, on a safer planet. The same objective was established by Adam Smith but forgotten on our 
way to unlimited growth, an economy that supply a plentiful revenue or subsistence for the people, which supply the state with sufficient revenue for the public services. These are worthy objectives that should be reported. Rebecca Henderson also believes that, for a better world, companies should transform into purpose driven organizations, cooperate, and establish financial metrics for a proper measurement (Henderson, 2020). It's useless to promise to be "truly committed for meeting the needs of all stakeholders" (Business Roundtable, 2019), and then to "fail to deliver fundamental shift in corporate purpose when enlightened purpose should be paramount" (Heskett, 2020). The truth is that income inequality has increased sharply in the last 50 years, with a dramatic rise for the top 1\% earners (Piketty, 2015), while in America, the gap between wealthiest and poorest Americans is the highest it has been in 50 years (Krugman, 2020). Inequality do most harm to equitable and sustainable economic growth and undermine social and political stability (Joseph E. Stiglitz, 2015). Proper measurement of what matters, transparency and real-time reporting are the answers for our problems. And technology could help us do this. "Who else but finance should be evaluating and prioritising investment in digital technology? Who else understands the systems end-to-end?" (Accenture, 2018).

Let us never forget that we, accountants, have an important role to play in this endeavour and it is our duty to work together for a common purpose, bringing value to society. It is a big challenge for us, life itself is a challenge, but we can think like this: "Life is difficult, but once we really understand this and accept it, then life doesn't seem difficult at all ${ }^{5 "}$.

High-quality business reporting is believed to be at the heart of strong and sustainable organizations, financial markets and economies (Bhasin, 2017), while real-time recording and presentation of financial data, not only that they are perceived by investors as having a more robust corporate governance system and attract investors (ACCA, 2013), but enhance the accuracy of financial information, helping audit work to be much more efficient on preventing fraud and assuring the public of accuracy of financial information (Billings et al., 2020). Auditors can identify high-risk financial positions promptly, given new capabilities offered by technology (Dai \& Vasarhelyi, 2017).

We have seen that technology changes accounting rules, and due to automation, makes accounting more reliable and useful for our society. Despite the recent efforts of the two international organizations, $\mathrm{IASB}^{6}$ and $\mathrm{FASB}^{7}$, there are still many differences between the two systems, creating real difficulties for investors and other stakeholders to assess and compare organizations. Future research is needed on the effects that technology has on accounting rules and reporting. Scholars have not given sufficient attention to new technologies, that is why research is urgently needed to understand accounting in a changing digital economy (Moll \& Yigitbasioglu, 2019). Major limitations of this paper are due to the complexity of the issues tackled; thus, they must be broken down and analysed in more detail.

\section{References}

ACCA (2013). Understanding investors: the road to real-time reporting ACCOUNTANTS FOR BUSINESS. www.accaglobal.com/ri.

Accenture (2018). The CFO Reimagined: from driving value to building the digital enterprise. https://www.accenture.com/t20180910T083815Z_w__/us-en/_acnmedia/PDF-85/Accen

\footnotetext{
${ }^{5}$ The Road Less Traveled: A New Psychology of Love, Traditional Values and Spiritual Growth, By M. Scott Peck.

${ }^{6}$ International Accounting Standards Board.

${ }^{7}$ Financial Accounting Standards Board.
} 
ture-CFO-Research-Global.pdf\#zoom =50.

Alaryan, L. A., Abu Haija, A. A., \& Alrabei, A. M. (2014). The Relationship between Fair Value Accounting and Presence of Manipulation in Financial Statements. International Journal of Accounting and Financial Reporting, 4(1), 221. https://doi.org/10.5296/ijafr.v4i1.5405.

Ariely, D. (2020). Column: You Are What You Measure. Harvard Business Review. https://hbr.org/2010/06/column-you-are-what-you-measure.

Benston, G. J. (2006). Fair-value accounting: A cautionary tale from Enron. Journal of Accounting and Public Policy, 25(4), 465-484. https://doi.org/10.1016/j.jaccpubpol.2006.05.003.

PICBE |

735

Bhasin, M. L. (2017). Integrated Reporting: The Future of Corporate Reporting. International Journal of Management and Social Sciences Research (IJMSSR), 6(February), 17-31. https://doi.org/10.1057/978-1-137-52766-0_21.

Billings, A., Billings, B., \& Musazi, B. G. N. (2020). Opportunities and Challenges of Real-Time Financial Reporting - The CPA Journal. The CPA Journal. https://www.cpajournal.com/ 2020/07/22/opportunities-and-challenges-of-real-time-financial-reporting/.

Burchell, S., Clubb, C., \& Hopwood, A. G. (1985). ACCOUNTING IN ITS SOCIAL CONTEXT: TOWARDS A HISTORY OF VALUE ADDED IN THE UNITED KINGDOM.

Business Roundtable. (2019). Business Roundtable Redefines the Purpose of a Corporation to Promote 'An Economy That Serves All Americans.' Business Roundtable Press Release, August(19), 1-4. https://www.businessroundtable.org/business-roundtable-redefines-thepurpose-of-a-corporation-to-promote-an-economy-that-serves-all-americans.

Capron, M. (1994). Contabilitatea în perspectivă.

Dai, J., \& Vasarhelyi, M. A. (2017). Toward blockchain-based accounting and assurance. Journal of Information Systems, 31(3), 5-21. https://doi.org/10.2308/isys-51804.

DeFond, M., Hu, J., Hung, M., \& Li, S. (2020). The effect of fair value accounting on the performance evaluation role of earnings. Journal of Accounting and Economics, 70(2-3), 101341. https://doi.org/10.1016/j.jacceco.2020.101341.

Enache, L., \& Srivastava, A. (2018). Should intangible investments be reported separately or commingled with operating expenses? New evidence. Management Science, 64(7), 34463468. https://doi.org/10.1287/mnsc.2017.2769.

Fanelli, D. (2010). Do pressures to publish increase scientists' bias? An empirical support from US states data. PLoS ONE, 5(4). https://doi.org/10.1371/journal.pone.0010271.

Fleming, S. (2020). How automation has affected jobs through the ages. World Economic Forum. https://www.weforum.org/agenda/2020/09/short-history-jobs-automation/.

Friedman, M. (1970). The Social Responsibility of Business is to Increase its Profits The New York Times Magazine.

Govindaranjan, V., Rajgopal, S., \& Srivastava, A. (2018). Why Financial Statements Don't Work for Digital Companies. https://hbr.org/2018/02/why-financial-statements-dont-work-fordigital-companies?ab=at_articlepage_recommendedarticles_bottom $1 \mathrm{x} 1$.

Hawksworth, J., Berriman, R., \& Saloni, G. (2018). Will robots really steal our jobs? An international analysis of the potential long term impact of automation Key findings: impact of automation. $P w C$.

Henderson, R. (2020). Reimagining Capitalism in a World on Fire. PublicAffairs; Illustrated edition (April 28, 2020).

Heskett, J. (2020). Are CEOs the Wrong Leaders for Stakeholder Capitalism? - Harvard Business School Working Knowledge. https://hbswk.hbs.edu/item/are-ceos-the-wrong-leaders-forstakeholder-capitalism. 
Hoogervorst, H. (2018). Do not blame accounting rules for the financial crisis | Financial Times. Financial Times. https://www.ft.com/content/bd084b5c-c623-11e8-86b4-bfd556565bb2.

Hopwood, A. G. (1976). Editorial. Accounting, Organizations and Society, 1(1), 1-4. https://doi .org/10.1016/0361-3682(76)90002-7.

Hopwood, A. G. (2007). Whither Accounting Research? The Accounting Research.

Horngren, C. T., Datar, S. M., \& Rajan, M. V. (2015). Cost accounting: a managerial emphasis (15th ed.). Pearson Education.

IASB (2015). International Financial Reporting Standards.

Ionascu, I. (1997). Epistemologia Contabilităţii. Editura Economică.

Jianu, I. (2007). Evaluarea, prezentarea și analiza performanței intreprinderii. Corpul Experților Contabili și Contabililor Autorizati din Romania.

Kothari, S. P., \& Lester, R. (2012). The Role of Accounting in the Financial Crisis: Lessons for the Future. SSRN Electronic Journal, 1-31. https://doi.org/10.2139/ssrn.1972354.

Krugman, P. (2020). Arguing with Zombies: Economics, Politics, and the Fight for a Better future. Lee, C. (2014). Why Fair-Value Accounting Isn't Fair| Stanford Graduate School of Business. Www.Gsb.Stanford.Edu. https://www.gsb.stanford.edu/insights/charles-lee-why-fair-valu e-accounting-isnt-fair.

Lev, B., \& Feng, G. (2016). The End of Accounting and the Path Forward for Investors and Managers. wiley.

Malciu, L., \& Feleagă, N. (2005). Reformă după reformă: contabilitatea din România în fața unei noi provocări. Editura Economică.

Man, M., \& Gădău, L. (2011). the Profit and Loss Account Through the Romanian Accounting Regulations. From European To International. Annals of the University of Petrosani: Economics, XI(2), 167-176.

Moll, J., \& Yigitbasioglu, O. (2019). The role of internet-related technologies in shaping the work of accountants: New directions for accounting research. British Accounting Review, 51(6). https://doi.org/10.1016/j.bar.2019.04.002.

Pantazi, M. (2020). Business, Management, Accounting and their role for Society. Emerging Markets Economics and Business. Contributions of Young Researchers. Proceedings of the 11th International Conference of Doctoral Students and Young Researchers, 337-340.

Piketty, T. (2015). Capital in the Twenty-first Century.

Raworth, K. (2017). Doughnut Economics. Random House Business.

Ristea, M., \& Dumitru, C. G. (2012). Libertate și conformitate în standardele și reglementările contabile. Editura CECCAR.

Sterling, R. R. (1975). Toward a Science of Accounting. Financial Analysts Journal, 31(5), 28-36. https://doi.org/10.2469/faj.v31.n5.28.

Stiglitz, J E. (2009). THE FINANCIAL CRISIS OF 2007/2008 AND ITS MACRO-ECONOMIC CONSEQUENCES.

Stiglitz, Joseph E. (2015). The Great Divide. Penguin Books.

Weber, M. (1947). The Theory of Social and Economic Organization The Theory of Social and Economic Organization. Free Press.

Wright, D., Witherick, D., \& Gordeeva, M. (2017). The robots are ready. Are you? Untapped advantage in your digital workforce. Deloitte, 28. https://www2.deloitte.com/content/ $\mathrm{dam} /$ Deloitte/tr/Documents/technology/deloitte-robots-are-ready.pdf. 